\title{
PENDIDIKAN MORAL ANAK USIA DINI MELALUI PENDEKATAN KONSTRUKTIVIS
}

\author{
Intan Kusumawati ${ }^{1}$, Darmiyati Zuchdi ${ }^{2}$ \\ ${ }^{1}$ Pendidikan Pancasila dan Kewarganegaraan, Universitas Cokroaminoto Yogyakarta \\ ${ }^{2}$ Ilmu Pendidikan, Universitas Negeri Yogyakarta \\ ${ }^{1}$ J1. Perintis Kemerdekaan, Gambiran, Umbulharjo, Kota Yogyakarta 55161 \\ ${ }^{2}$ Jl. Kolombo No. 1 Karangmalang, Catur Tunggal, Depok, Sleman 55281 \\ ${ }^{1}$ Email: intan.kusumawati@ucy.ac.id \\ ${ }^{2}$ Email: darmiyatizuchdi@gmail.com
}

\begin{abstract}
ABSTRAK
Pendidikan moral anak usia dini melalui pendekatan konstruktivis berfokus pada pelaksanaan praktik keseharian yang sesuai dengan perkembangan anak sejak lahir. Melalui pendekatan konstruktivis maka tujuan dari penelitian ini adalah mengetahui perkembangan anak dalam semua bidang kurikulum dan semua domain perkembangan berkembang, baik fisik ataupun moralnya. Tujuan pendidikan moral anak usia dini melalui pendekatan konstruktivis agar kelak anak menjadi pelajar yang mandiri. Dalam pembelajaran dengan menggunakan pendekatan konstruktivis memberikan kesempatan anak untuk belajar tentang isu-isu dan perilaku moral secara pengalaman nyata. Anak membangun pemahaman moral melalui interaksi social yang dialaminya. Guru kontruktivis memfasilitasi anak di dalam ruang kelas agar siswa dapat terlibat langsung dalam menyelesaikan konflik ataupun masalah yang dialami siswa di kelas, mengambil keputusan dan isu-isu sosial. Guru konstruktivitis membangun minat dan tujuan anak dalam membangun penalaran anak, eksperimen anak serta memberikan dorongan anak agar bisa bekerjasama antar semua anggota kelas. Hasil penelitian ini bahwa pendekatan konstruktivis yang dilakukan di kelas menjadikan anak bisa otonom serta dapat mengambil keputusan, anak dapat melakukan permainan dalam kelompok lewat kerjasama, serta dapat melakukan diskusi ataupun musyawarah sosial maupun moral.
\end{abstract}

Kata kunci : Pendidikan moral, pendidikan anak usia dini, pendekatan konstruktivis.

\begin{abstract}
Early childhood moral education through constructivist approaches focuses on implementing daily practices that are appropriate to the development of children from birth. Through a constructivist approach, the purpose of this study is to find out the development of children in all areas of the curriculum and all domains of development, both physical and moral. The goal of early childhood moral education is through a constructivist approach so that later children become independent students. In learning using a constructivist approach gives children the opportunity to learn about moral issues and behavior in real experience. Children build moral understanding through the social interactions they experience. Constructivist teachers facilitate children in the classroom so students can be directly involved in resolving conflicts or problems experienced by students in class, making decisions and social issues. The constructivist teacher builds children's interests and goals in building children's reasoning, children's experiments and encouraging children to be able to cooperate among all class members. The results of this study that the constructivist approach taken in the classroom makes children able to be
\end{abstract}


autonomous and can make decisions, children can play games in groups through cooperation, and can conduct discussions or social and moral deliberations.

Keywords: moral education, early childhood education, constructivist approach.

\section{PENDAHULUAN}

Dalam pendidikan anak usia dini perlu ditanamkan pendidikan moral atau karakter yang baik agar menjadi bekal anak ketika kelak mejadi dewasa di masa depannya. Pendidikan karakter selama ini telah diberikan pada anak baik secara langsung ataupun tidak langsung baik di rumah, di sekolah ataupun di lingkungan masyarakat. Di Indonesia menurut Zuriah (2007: 10-12) muncul tuntutan untuk menyelenggarakan pendidikan moral terutama didasarkan pada tiga pertimbangan sebagai berikut: (1) Melemahnya ikatan keluarga. Keluarga yang secara tradisional merupakan guru pertama bagi anak, mulai kehilangan fungsinya, (2) Kecenderungan negatif di dalam kehidupan remaja dewasa ini, (3) Perlunya nilai-nilai etika, moral, dan budi pekerti. Oleh karena itu orang tua ataupun pendidik memiliki kewajiban mendorong tumbuhnya moralitas dasar dengan cara mengajar kepada generasi muda agar menghormati nilai-nilai tersebut.

Pendidikan moral anak usia dini melalui pendekatan konstruktivis pada pendidikan anak usia dini berfokus pada praktek yang sesuai dengan perkembangan anak sejak lahir sampai delapan tahun (Bredekamp, 1987; Bredekamp \& Copple, 1997). Tujuan pendidikan konstruktivis adalah mempromosikan perkembangan anak dalam semua bidang kurikulum (sains, matematika, bahasa dan baca tulis, ilmu sosial, dan seni), dan dalam semua domain perkembangan (intelektual, fisik, sosial, emosi dan moral) (De Vries, Zan, Hildebrantdt, Edmiaston, \& Sales, 2002: Fosnot, 2005).

Istilah konstruktivis berasal dari teori perkembangan piaget. Menurut Piaget, anakanak membangun (countract) pengetahuan dan kecerdasan mereka melalui interaksi dengan dunia fisik dan sosial mereka (Piaget, 1970; Kamii \& Ewing, 1996). Pendidikan konstruktivis berakar kuat dalam gerakan pendidikan progresif dan mendasarkan pemikiran teoritis dan praktisnya dari filsuf pendidikan seperti John Dewey (1909). Dalam pembelajaran guru yang menggunakan pendekatan konstruktivis menut Nucci, L.P, \& Narvaes, D.( 2008: 363) mengatakan: “The constructivist teacher implemented a program similar to the constructivist approach described above. The curriculum was child-centered and interest-driven". Guru kontraktivistis menerapkan program serupa dengan pendekatan konstruktivistis sebagaimana di jelaskan di atas. Kurikulum terpusat pada anak dan didasarkan minat anak. Anak-anak terlibat dalam kegiatan yang dipilih dengan bebas. Guru 
membentuk suasana kelas yang didasarkan pada sikap saling menghormati, meminimalisirkan penggunaan otoritasnya sendiri, bekerjasama dengan anak-anak sebanyak mungkin, dan anak-anak teribat dalam resolusi konflik. Ia tidak menggunakan hukuman, ancaman, ancaman hukuman, atau imbalan, melainkan bekerja untuk membantu anak-anak belajar bagaimana mengelola perilaku mereka sendiri.

Pelaksanaan pendidikan karakter selama ini kurangnya peran ibu dalam mengkarakterkan anak di rumah karena ibu bekerja, berkembangnya lembaga dan pelayanan PAUD serta sekolahan yang diharapkan bisa memberikan pendidikan karakter agar anak menjadi anak yang baik. Pendidikan karakter bagi anak sejak dini perlu dilakukan oleh orang tua di rumah. Menurut pengamat social, terjadi krisis moral karena dari kesalahan lembaga pendidikan nasional yang kurang optimal membentuk kepribadian peserta didik. Lembaga pendidikan dinilai besar memberikan transmisi pengetahuan namun melupakan pengembangan sikap, nilai dan perilaku dalam pembelajarannya. Orientasi pendidikan nasional cenderung melupakan pengembangan dimensi nilai (affective domain) merugikan anak atau peserta didik secara individual maupun kolektif. Anak akan mengalami perkembangan intelektual tidak seimbang dengan kematangan kepribadian sehingga melahirkan sosok special yang kurang peduli dengan lingkungan sekitarnya dan rentan mengalami disortasi social (Zubaedi, 2005: 2).

Budi pekerti merupakan nilai-nilai hidup manusia yang sungguh-sungguh dilaksanakan bukan sekedar kebiasaan, tapi berdasarkan pemahaman dan kesadaran diri untuk menjadi baik. Nilai-nilai yang didasari akan dilaksanakan sebagai budi pekerti hanya dapat diperoleh melalui proses yang berjalan sepanjang hidup manusia. Budi pekerti melalui proses internalisasi dari apa yang baik dalamkehidupan manusia (Zuriah, 2007: $38)$.

Pendidikan moral atau nilai menurut Zuchdi (2010: 5) dapat disampaikan dengan metode langsung ataupun tidak langsung. Metode langsung mulai dari penentuan perilaku yang dinilai baik, sebagai indoktrinasi berbagai ajaran. Caranya dengan memusatkan perhatian secara langsung pada ajaran tersebut, lewat mendiskusikan, mengilustrasikan, menghafalkan dan mengucapkannya. Metode tidak langsung tidak dimulai dengan menentukan perilaku yang diinginkan, tetapi dengan menciptaan situasi yang memungkinkan perilaku yang baik dapat dipraktikkan. Keseluruhan pengalaman di sekolah dimanfaatkan untuk mengembangkan perilaku yang baik.

Dengan memperkaya dimensi nilai, moral dan norma pada aktivitas pendidikan, $\underline{\text { akan memberikan pegangan hidup yang kokoh bagi anak-anak dalam menghadapi }}$ 
perubahan social. Kematangan secara moral akan menjadikan seorang anak mampu memperjelas dan menentukan sikap terhadap substansi nilai dan norma baru dalam masyarakat. Dengan bekal pendidikan budi pekerti akan memperkuat konstruksi moralitas peserta didik sehingga mereka tidak gampang goyah dalam menghadapi aneka macam godaan dan rayuan dalam kehidupannya (Zubedi, 2005: 3). Oleh karena itu, penanaman nilai-nilai budi pekerti atau moral haruslah ditanamkan sejak anak usia dini, sehingga hal tersebut mendarah daging dalam kehidupan anak tersebut sampai dewasa nanti.

Komponen sekolah ketika dilibatkan (sudrajat dalam Zuchdi, 2011: 152) dalam pembudayaan dan penanaman karakter, berarti nilai, norma, kebiasaan-kebiasaan karakter yang sudah dipriopritaskan harus dimodelkan oleh semua warga sekolah. Sementara orangtua/wali harus memperhatikan perkembangan karakter anak-anak mereka ketika berada di rumah; demikian juga dengan proyek-proyek sosial yang disiapkan oleh komite sekolah dan masyarakat.

Pemerintah telah mengesahkan UU No. 20 Tahun 2003 tentang Sistem Pendidikan Nasional yang secara eksplinsit mencantumkan tentang pendidikan anak usia dini (Pasal 28), dengan begitu pemerintah pada khususnya dan bangsa Indonesia pada umumnya sudah mengakui bahwa pendidikan anak usia dini sebagai hal yang sangat penting untuk menyiapkan sumber daya manusia di masa yang akan datang. Pendidikan yang tepat untuk anak usia dini akan menjadi landasan bagi anak untuk memasuki pendidikan selanjutnya (SD, SMP, SMA, dan Perguruan Tinggi).

Anak usia dini adalah anak yang berumur 0-6 tahun (ini merupakan patokan di Indonesia berdasarkan UU No. 20 Tahun 2003 tentang Sistem Pendidikan Nasional, namun secara internasional usia 0-8 tahun). Pada usia ini otak anak sedang berkembang dengan pesatnya sebesar $50 \%$, perkembangan $80 \%$ pada saat anak berusia 8 tahun, dan perkembangan sempurna $100 \%$ apabila anak sudah memasuki usia 18 tahun. Perkembangan yang pesat adalah periode usia dini sehingga sangat diperlukan rangsangan yang optimal dan porsi yang tepat dan akurat.

Anak usia dini adalah kelompok anak yang berada dalam proses pertumbuhan dan perkembangan yang bersifat unik, dalam arti memiliki pola pertumbuhan dan perkembangan (koordinasi motorik halus dan kasar), intelegensi (daya pikir, daya cipta, kecerdasan emosi, dan kecerdasan spiritual), sosial emosional (sikap dan perilaku serta agama), bahasa dan komunikasi yang khusus sesuai dengan tingkat pertumbuhan dan perkembangan anak. Berdasarkan keunikan dalam pertumbuhan dan perkembangannya, anak usia dini terbagi dalam 3 tahap yaitu (1) masa bayi lahir sampai berusia 12 bulan, (2) 
masa toddler (batita) usia 1-3 tahun, (3) masa prasekolah usia 3-6 tahun, (4) masa kelas awal SD usia 6-8 tahun). Pertumbuhan dan perkembangan anak usia dini perlu diarahkan pada peletakan dasar-dasar yang tepat bagi pertumbuhan dan perkembangan manusia seutuhnya, yaitu pertumbuhan dan perkembangan fisik, daya pikir, daya cipta, sosial emosional, bahasa dan komunikasi yang seimbang sebagai dasar pembentukan pribadi yang utuh ( Mansur, 2007: 83-84).

Pendidikan anak usia dini di dalam UU No. 20 Tahun 2003 tentang Sistem Pendidikan Nasional, didefinisikan pendidikan anak usia dini sebagai berikut:

"Pendidikan anak usia dini adalah suatu upaya pembinaan yang ditujukan kepada anak sejak lahir sampai dengan usia 6 tahun yang dilakukan melalui pemberian rangsangan pendidikan untuk membantu pertumbuhan dan perkembangan jasmani dan rohani agar anak memiliki kesiapan dalam memasuki pendidikan lebih lanjut". Adapun upaya yang dilakukan untuk melakukan pembinaan kepada anak adalah meliputi stimulasi intelektual, pemeliharaan kesehatan, pemberian nutrisi, dan penyediaan kesempatan yang luas untuk mengeksplorasi dan belajar secara aktif.

Mansur (2007: 94-95) menyatakan pendidikan anak usia dini ada tiga landasan yaitu: landasan yuridis, landasan empiris dan landasan keilmuan. Landasan yuridis atau hukum terkait dengan pentingnya pendidikan anak usia dini tersirat dalam amandemen UUD 1945 pasal 28 b ayat 2, yaitu: "Negara menjamin kelangsungan hidup, pengembangan dan perlindungan anak terhadap eksploitasi dan kekerasaan”. Pemerintah Indonesia juga telah menandatangani Konvensi Hak Anak melalui Keppres No. 36 Tahun 1990 yang mengandung kewajiban Negara untuk pemenuhan hak anak. Secara khusus pemerintah juga telah mengeluarkan UU No. 20 Tahun 2003 tentang Sistem Pendidikan Nasional, intinya pendidikan anak usia dini meliputi semua pendidikan anak usia dini, apapun bentuknya diselenggarakan dan siapapun yang menyelenggarakannya.

Landasan empiris menunjukkan dari segi pemerataan pendidikan di Indonesia baik melalui jalur pendidikan sekolah maupun luar sekolah menunjukkan bahwa anak usia dini yang memperoleh pelayanan pendidikan anak pra sekolah sudah cukup perlu lebih ditingkatkan. Menurut Direktur Jenderal PAUD dan Dikmas, Harris Iskandar peningkatan kualitas dan kuantitas PAUD, telah masuk dalam Program Prioritas Pendidikan Nasional. Harris mengatakan melalui Perpres 59 Tahun 2017, Indonesia menjamin setiap anak perempuan dan laki-laki mendapat akses pengasuhan PAUD. "Target Agenda Pendidikan 2030 untuk PAUD adalah memastikan seluruh anak laki-laki dan perempuan memperoleh akses terhadap perkembangan, perawatan dan pendidikan pra-SD (PAUD) yang bermutu untuk menjamin kesiapan memasuki pendidikan dasar," 
ujarnya.Pendidikan Anak Usia Dini (PAUD) merupakan salah satu program prioritas pembangunan pendidikan nasional, yang diarahkan demi mewujudkan pendidikan yang berkeadilan, bermutu dan relevan dengan kebutuhan masyarakat. Kebijakan tersebut bertumpu di atas prinsip ketersediaan lembaga PAUD yang dapat diakses oleh seluruh lapisan masyarakat, keterjangkauan layanan PAUD sesuai dengan kemampuan masyarakat, kualitas layanan PAUD dalam mendidik dan mengasuh anak usia 0-6 tahun, kesetaraan layanan PAUD untuk setiap kelompok masyarakat, dan kepastian setiap anggota masyarakat dalam memperoleh layanan PAUD.

Target penyediaan pendidikan yang berkualitas menjadi poin keempat dari tujuan pembangunan berkelanjutan (Sustainable Development Goals/SDGs). Target ini biasa disebut Agenda Pendidikan 2030, salah satunya menargetkan seluruh anak-anak mendapatkan akses Pendidikan Anak Usia Dini (PAUD) atau pendidikan pra-SD, melalui program wajib PAUD satu tahun pra SD. "Saat ini APK (Angka Partisipasi Kasar) PAUD telah menunjukkan persentase yang cukup baik yaitu 72,35 persen, walaupun masih ada yang di bawah rata-rata APK nasional," ujarnya. Saat ini terdapat sekitar 190.000 PAUD dan 600.000 guru yang mengajar 6 juta anak usia dini. "Walau demikian masih banyak anak-anak yang belum dilayani. Oleh karena itu, sesuai dengan Nawacita membangun dari pinggiran, Pemerintah Indonesia membantu masyarakat desa di daerah terdepan, perbatasan dan pedalaman untuk menginisiasi terbentuknya PAUD baru," Dari data tersebut, masih ada sekitar 6.284.920 anak atau sekitar 34,84 persen anak yang belum memperoleh layanan anak usia dini. Dari data desa, masih ada sekitar 23.737 desa yang belum ada layanan Pendidikan Anak Usia Dini. (https://inforial.tempo.co/info/1000326/standar-pelayanan-minimal-dan-kebijakan-terkinipaud-dan-dikmas-tahun-2018, diunggah Rabu, 3 Desember 2018).

Kemudian landasan keilmuan yang melandasi pentingnya pendidikan anak usia dini. Otak yang secara fisik merupakan organ lembut di kepala memiliki peran sangat penting, selain sebagai pusat syaraf juga berperan dalam menentukan kualitas kecerdasan seseorang. Bayi yang baru lahir memiliki lebih dari 100 milyar sel otak atau sekitar 1 trilyun sel glia yang berfungsi sebagi perekat serta synap (cabang-cabang sel otak) yang akan membentuk sambungan antar sel otak. Kaitan dengan pendidikan anak usia dini, seiring dengan perkembangan zaman banyak orangtua yang keduanya bekerja sehingga tidak mempunyai kesempatan untuk menjaga anaknya akhirnya menitipkan anaknya di taman penitipan anak atau lembaga pendidikan anak usia dini.di sini diperlukan pendidikan $\underline{\text { moral dengan menggunakan pendekatan konstruktivis agar anak bisa mencapai }}$ 
perkembangan yang optimal dalam hal intektual, emosi dan moral. Dari uraian yang dijelaskan di atas maka dalam penelitian yang akan dilakukan berjudul "Pendidikan moral anak usia dini melalui pendekatan konstruktivis".

Rumusan permasalahan yang muncul adalah : (1) Nilai moral apa saja yang ditanamkan pada anak usia dini?, (2) Metode pembelajaran pendidikan moral yang bagaimana yang akan diberlakukan pada anak usia dini?, (3) Apa saja faktor pendorong dan penghambat yang dihadapi pendidik atau orang tua dengan menggunakan pendekatan konstruktivis?

\section{METODE PENELITIAN}

Penelitian ini merupakan penelitian kualitatif. Setting penelitian di Taman Kanakkanak Aisyiyah Bustanul Athfal Saman RT 03, Bangunharjo Sewon Bantul. Waktu penelitiannya selama 3 bulan yaitu bulan Agustus - Oktober 2018. Subjek penelitiannya yaitu pengelola, pendidik, peserta didik dan orangtua peserta didik. Metode pengumpulan data dilakukan dengan wawancara, observasi, dan dokumentasi.Teknik analisa data yang digunakan terdiri dari reduksi data, menampilkan data dan verifikasi data. Keabsahan data dengan trianggulasi.

\section{HASIL PENELITIAN DAN PEMBAHASAN}

Dalam membelajaran pendidikan moral melalui pendekatan konstruktivis pada pendidikan anak usia dini berfokus pada praktek yang sesuai dengan perkembangan anak sejak lahir sampai 8 tahun dengan tujuan pendidikan konstruktivis adalah mempromosikan perkembangan anak dalam semua bidang kurikulum dan dalam semua domain. Anak-anak ketika belajar dan bermain di dalam kelas ataupun di luar kelas membangun pengetahuan dan kecerdasan mereka melalui interaksi dengan dunia fisik dan sosial mereka. Pendidikan konstruktivis berakar kuat dalam gerakan pendidikan progresif.

Prinsip penting yang digunakan dalam pendekatan konstruktivis adalah menciptakan situasi dan kondisi yang saling hormat dan terjadi suasana sosiomoral secara terus menerus. Adanya jalinan hubungan inter personal anak di dalam kelas, interaksi dengan teman, interaksi dengan guru atau orang dewas maupun hubungan orang dewasa dengan orang dewasa yang diamati langsung oleh anak-anak.

Di dalam kelas konstruktivitis memberikan kesempatan anak untuk belajar mengenai isu-isu dan perilaku moral yang didasarkan dan pengalaman langsung dengan cara membangun pemahaman moral anak. Di kelas guru memberikan pengajaran kepada 
anak agar kelas bisa dijadikan tempat belajar yang bisa digunakan untuk kegiatan membangun minat dan tujuan anak agar anak dapat melakukan penalaran dan eksperimen dalam anggota komunitas kelas. Guru sebagai orang dewasa memberikan mengarahan kepada anak dalam pembuatan aturan dan pengambilan keputusan dalam kelas. Siswa atau anak dalam belajar melalui permainan kelompok dan diskusi sosial akan mendapatkan pelajaran dalam pengembangan moral.

Guru dapat melihat bagaimana anak bersosialisasi dan melakukan kehidupan sosial di antara anak-anak. Di Kehidupan kelas anak dapat mengembangkan kecerdasan melalui berbagai permainan sosial lewat setiap kegiatan yang dilalauinya. Pengembangan moral akan tampak ketika anak berinteraksi dengan teman yang lain, dengan guru dan dengan lingkungannya. Anak belajar bersosialisasi dengan lingkungan dan akan meningkatkan perkembangan kepribadiannya. Perkembangan yang terjadi tentunya karena adanya aksi dan refleksi yang di lakukan dalam kegiatan di kelas. Menurut Piaget dalam Hildebrandt \& Zan (Nucci \& Narvaez, 2014: 513) Anak anak membangun dan membangun kembali pengetahuan mereka tentang dunia untuk memahaminya, yang pada akhirnya sampai pada bentuk penalaran dan perilaku yang semakin lama semakin memadai. Pengembangan moral anak berkembang ketika anak berinteraksi di dalam kelas dengan teman-temannya ketika melakukan kegiatan permainan di kelas. Bagaimana anak akan menunjukkan sikap sportif dalam bermain, tidak melakukan perbuatan curang dan bergantian menggunakan permainan dengan temannya.

Di Taman Kanak Kanak Aisyiyah Bustanul Athfal Saman mengembangkan pendidikan budi pekerti meliputi : (1) Kejujuran dan tanggungjawab, (2) Kepekaan sosial emosional, (3) Sopan santun, (4) Kebersihan serta terpenting adalah (5) Keagamaan. Perilaku dasar dalam pembentukan kepribadiannya merupakan dasar sikap budi bekrti yang baik. Dengan mempunyai kepribadian yang baik akan menjadi pedoman perilaku anak dalam berinteraksi dengan teman, saudara, sahabat, orang tua dan masyarakat serta kelak kehiupannya berbangsa dan bernegara.

Kegiatan penanaman pendidikan moral dengan pendekatan konstruktivitis meliputi kegiatan keagamaan dengan memulai semua kegiatan dengan berdoa. Doa yang diajarkan adalah doa mau memulai belajar, doa untuk kedua orangtua, doa akan makan dan minum serta mendoakan semua kaum muslimin dan musimat. Kegiatan sopan santun yang dilakukan anak adalah menghormati teman, guru, orangtua dengan berjabat tangan dan memberikan salam ketika bertemu ataupun berpamitan. Menyayangi teman, saudara, guru dan orangtua, saling memberikan bantuan, memberikan makanan dan minuman kepada 
teman yang tidak membawa, bergantian alat permainan dengan teman. Berbicara jujur serta bekertanggungjawab terhadap tugas yang diberikan guru. Duduk dengan sopan dan rapi ketika pelajaran. Makan dan minum dengan baik dan sopan serta diawali dan diakhiri dengan doa. Menjaga kebersihan kelas dan lingkungan sekolah. Mengumpulkan uang sosial untuk korban bencana alam serta mengunjungi teman yang sakit. Berkata dengan nada yang rendah dan sopan dalam meminta bantuan kepada teman ataupun guru. Mengucapkan permintaan maaf dengan tulus dan tidak mengulangi kesalahan. Mengucapkan terimakasih ketika menerima sesuatu atau menerima bantuan dari orang lain. Sikap dan perilaku yang baik dan terus dilakukan akan menjadi tabiat baik.

Menjadi pribadi yang bisa menyenangkan atau menghibur teman yang sedih. Menjawab dengan baik dan sopan jika ditanya. Berjalan dengan tertib dan sopan. Dalam hal menjaga kebersihan, anak diharapkan bisa menjaga kebersihan dengan membuang sampah pada tempatnya. Cuci tangan sebelum makan dan mencuci tangan setelah makan ataupun setelah bermain dengan antri dan hemat air. Anak anak merapikan kembali mainan yang tadi dipakai untuk bermain dan mengembalikan pada tempat semula. Penanaman nilai kejujuran dengan bersikap dan berperilaku apa adanya, sesungguhnya dan tidak berbohong meruppakan tindakan yang terpuji dilakukan anak usia dini. Kejujuran mesti dipegang teguh dalam kehidupan sehari-hari agar menjadi kebiasaan yang baik. Tanggungjawab serta kedislipinan anak perlu ditanamkan sejak dini, contohnya anak setelah bermain merapikan kembali mainannya, disiplin dalam belajar, dalam kehadiran tiba ke sekolahan, disiplin dimulai dari rumah dari mulai bangun pagi, mandi, berpakaian, sholat subuh, sarapan pagi, berangkat sekolah, pulang sekolah, istirahat siang dan tidur di malam hari. Cara menanamkan kedisiplinan tidak hanya lewat suritauladan namun lewat lagu ataupun nyanyian seperti lagu Bangun tidur. Untuk kemandirian perlu ditanamkan sejak usia dini agar menjadi anak yang mandiri dan tidak tergantung kepada orang lain.

Menanamkan pendidikan moral terhadap anak usia dia memanglah tidak mudah, butuh kesabaran dan bimbingan yang terus menerus. Dibutuhkan kesabaran yang maksimal dan ketekunan yang ekstra dari guru , pendidik ataupun orangtua. Pendekatan yang digunakan dalam pembelajaran adalah pendekatan konstruktivitis dengan berorientasi kada kebutuhan anak, kreatif dan inovatif, lingkungan yang kondusif dengan belajar melalui bermain, menggunakan pembelajaran terpadu, mengembangkan ketrampilan hidup, menggunakan berbagai media dan sumber belajar serta pembelajaran yang berorientasi pada prinsip perkembangan anak. 
Metode pembelajaran yang digunakan untuk anak usia dini hendaknya kegiatannya menantang, menyenangkan, melibatkan unsur bermain, bergerak, bernyanyi, dan belajar. Guru atau pendidik serta orang tua mestinya memberikan contoh langsung atau suri tauladan kepada anak agar efektif untuk menanamkan nilai pendidikan moral kepada anak, jangan mendekte, menyuruh atau sekedar menasehati namun memberikan contoh menjadi teladan. Dalam menanamkan pendidikan moral orangtua atau guru perlu mengunakan teknik mendongen g karena mendongeng merupakan cara efektif dalam menanamkna pendidikan moral kepada anak usia dini. Anak anak usia dini tertatarik dengan buku cerita bergambar yang berwarna-warni, anak menarik perhatian anak. Guru bisa mendongeng secara lesan ataupun dengan alat peraga. Di dalam cerita dongeng yang disisipkan nilai nilai moral akan menanamkan nilai budi pekerti anak.

Perkembangan moral menurut Kohlberg (Zuriah, 2007: 35) terdapat tiga tingkatan berbeda, yaitu tingkat pra konvensial, tingkat konvensional dan tingkat pasca konvensional. Dalam pendidikan anak usia dini terdapat tahapan perkembangan tersebut. Tahap Pertama yaitu pada tahap orientasi pada hukuman dan ketaatan. Tahap ini menekannkan pada akibat fisik suatu perbuatan menentukan baik dan buruknya tanpa menghiraukan arti dan nilai manusiawi dari akibat tersebut. Anak menghindari hukuman ebih dikarenakan rasa takut, bukan karena rasa hormat. Tahap Kedua yaitu orientasi hedonis (keputusan individu) perbuatan yang benar adalah perbuatan yang memuaskan kebutuhan individu sendiri, tetapi juga kadang mulai memperhatikan kebutuhan orang lain. Hubungan lebih menekannkan unsur timbal balik dan kewajaran. Tahap ketiga yaitu orientasi anak manis. Anak memenuhi harapan keluarga dan lingkungan sosialnya yang dianggap bernilai pada dirinya sendiri. Unsur pujian menjadi penting pada tahap ini. Tahap keempat yaitu orientasi terhadap hukuman dan ketertiban. Menjalankan tugas dan rasa hormat terhadap otoritas adalah tindakan yang benar. Tahap kelima yaitu orientasi kontak sosial legalitas yaitu perbuatan yang benar cenderung didefinisikan dari segi hak-hak bersama dan ukuran-ukuran yang telah diuji secara kritis dan disepakati oleh seluruh masyarakat. Tahap keenam yaitu orientasi suara hati. Orientasi pada keputusan suara hati dan prinsip-prinsip etis yang telah dipilih sendiri, yang mengaju pada pemahaman logis menyeluruh, universal dan konsisten.

Seorang anak dalam pengembangan moralnya akan diarahkan dalam pembentukan totalitas kepribadian dari usia dini yang dimulai dari mengetahui kebajikan, merasakan, mencintai, menginginkan, hingga akhirnya akan melakukan kebajikan. Seorang anak akan mengalami perkembangan moralitas positif jika ia telah memiliki kesadaran moral 
sehingga dapat menilai dan membedakan hal-hal yang baik dan buruk. Anak yang bermoral dengan sendirinya akan dalam penilaian dan penalaran moralnya serta pada perilakunya yang baik, benar dan sesuai dengan etika.

Pengembangan moral anak usia dini di TK ABA Saman dengan pendekatan konstruktivis meliputi aspek ketrampilan sosial. Kecerdasan anak usia dini meliputi kegiatan bermain di ruang bermain, yang terdiri dari bermain purzel, bermain origami, bermain balok balok kayu, perahu goyang, bermain alat alat masak, serta bermain alat pertukangan. Kegiatan belajar yang dilakukan dari pengenalan diri dan lingkungan, mengenal macam-macam buah buahan, mengeanl macam-macam binatang, mengenal hubungan sebab akibat, mengenal bunyi-bunyian, suara alat musik, mengenal warna, bentuk dan ukuran, mengenal konsep waktu, mengenal hitungan sederhana, dan merasaakan suatu makanan, dan menyiapkan serta menyajikan makanan burger dan minuman susu serta belajar membatik.

Peran pengasuh dan guru di dalam kegiatan pembelajaran di kelas adalah memberikan kebebasan dan keleluasaan kepada anak untuk bermain sesuai dengan bakat dan keinginannya ataupun minat anak. Memperhatikan dan memantau anak ketika dalam kegiatan serta mendamaikan dan menjelaskan kepada anak ketika terjadi kesalahpahaman. Anak anak juga diberikan kesempatan untuk menyampaikan alasan, tanggapan, ide serta anak usia dini diberikan kesempatan berpikir menghubungkan konsep satu dengan konsep yang lainnya. Anak diberi waktu untuk menginggat kembali pengetahuan yang didapatkan dengan menyampaikan kembali ke guru ataupun pengasuh. Dalam menanamkan pendidikan moral ditanamkan sejak dini budi peketi anak usia dini dimana anak membutuhkan bimbingan atau suri tauladan sehingga anak bisa membiasakan diri untuk menghias dirinya dengan perilaku yang baik, sopan, terouji berakhlak dan berbudi pekerti yang luhur. Di sini perlunya guru atau pendidik dalam memberikan suri tauladan agar anak dapat menyerap apa yang merika ketahui, mereka lihat, mereka amati dan mereka lakukan dengan melaksanakan budi pekerti yang baik.

Faktor faktor pendorong pendidik dan orang tua adalah anak didik yang semangat dan memiliki ambisi yang besar dalam belajar. Orang tua yang peduli dengan pendidikan anaknya dengan memberikan bantuan dana dan sarana serta prasarana yang bisaa mendukung dan terlaksananya kegiatan pembelajaran di sekolah. Faktor penghambat yang dihadapi pendidik atau orang tua dengan menggunakan pendekatan konstruktivis yaitu terbatasnya alat edukasi pendidikan yang ada di dalam kelas. Guru sering menghadapi anak yang rewel, berebutan dengan teman ketika bermain mainan, saling menganggu serta 
belum dapat difungsikannya alat permainan edukatif (APE) secara maksimal terbatasnya jumlah pengasuh sehingga pekerjaan menjadi ganda. Ruangan sekolah yang kurang luas yang menjadikan anak kurang bebas dan luas dalam bermain serta halaman sekolah yang sempit menjadikan kegiatan belajar tidak bisa maksimal.

Upaya untuk mengatasi penghambat tersebut TK ABA Saman berupaya untuk membagi tugas sebagai pendidik dan pengasuh diperjelas sehingga tugas tidak tumpang tindih. Apabila tenaga pengasuh kurang bisa merekrut tenaga edukasi yang berkompeten dengan konsekuensi adanya kecukupan dana. Guru atau tenaga pendidik harus bisa memahami karakteristik anak yang beragam dengan penuh kesabaran dan ketelatenan dalam mendidik, mendampingi dan menanamkan pendidikan moral dengan ikhlas dan penuh tanggungjawab.Perlunya adanya komunikasi yang baik dengan orangtua agar kegiatan pembelajaran dan pengembangan moral anak tercapai, tentunya dengan komunikasi yang intens dan rutin agar sekolah dan orang tua bisa memantau dan mendampingi tumbuh kembang anak baik motorik halus atapun kasar. Sarana dan prasarana pendukung perlu ditingkatkan agar kegiatan bisa berjalan dengan baik dan lancer tanpa hambatan.

\section{KESIMPULAN}

Pendidikan moral pada anak usia dini melalui pendekatan konstruktivitis menjadikan anak atau pelajar otonom selamanya. Anak akan dipandu oleh akal dan pikiran serta keyakinan juga komitmen.Bimbingan guru atau orang dewasa adalah memberikan bantuan pada kebebasan anak. Belajar di sini menjadikan anak bebas memilih apa yang akan diketahuinya, anak akan belajar bersama melalui saling memberi dan menerima. Guru tidak hanya memberi namun juga menerima dari anak. Anak belajar melalui proses di kelas secara kecerdasan sosial.

\section{DAFTAR PUSTAKA}

Bredekamp, S. 1987. Developmentally appropriate practice in early childhood programs serving children from birth to age 8. Wangshington, D.C.: National Association for the education of young children.

Bredekamp, S., \& Copple, C. 1997. Developmentally appropriate practice in early childhood programs. Wangshington, D.C.: National Association for the education of young children.

DeVries, R.2002. What does research tell us about effective teaching? Des Moines, IA: The Iowa Acad-emy of Education, sponsored by the FINE Foundation. 
Dewey.J. 1909. Moral principles in education. Boston: Houghton Mifflin.

Fosnot, C. T. 2005. Constructivism:bTheory, perspectives, and practice. New York: Teacher College Press.

Https://inforial.tempo.co/info/1000326/standar-pelayanan-minimal-dan-kebijakan-terkinipaud-dan-dikmas-tahun-2018, diunggah Rabu, 9 Januari 2019.

Kawii, C., \& Ewing, J.K.(1996). Basing teaching on Piaget's constructivism, Childhood education. 72, 260-264.

Mansur. 2007. Pendidikan usia dini dalam Islam. Yogyakarta: Pustaka Pelajar.

Nucci, Larry, P. \& Narvaez, Darcia. 2014. Handbook Pendidikan Moral dan Karakter. Handbook of moral and character education. Bandung: Nusa Media.

Nucci, LarryP. \& Narvaez, darcia. Eds. 2008. Handbook of moral and character education. New York and London: Routledge Taylon \& Francis Group.

Nurul Zuriah. 2007. Pendidikan moral dan budi pekerti dalam perspektif perubahan: Menggagas platform pendidikan budi pekerti secara kontekstual dan futuristikc. Jakarta: Bumi Aksara.

Piaget, J. 1970. Piaget's theory. In carmichael's manual of child pasychology ( $3^{\text {rd }}$ ed.). New York: Wiley.

Zubaedi. 2005. Pendidikan berbasis masyarakat, upaya menawarkan solusi terhadap berbagai problem sosial. Yogyakarta: Pustaka pelajar.

Zuchdi, D. 2011. Pendidikan Karakter dalam perspektif teori dan praktik. Yogyakarta: UNY Press.

Zuchdi, D.2010. Humanisasi Pendidikan: Menemukan kembali pendidikan yang manusiawi. Jakarta: Bumi Aksara. 